\title{
30 éves a Tér és Társadalom
}

\section{0 years of Tér és Társadalom}

\section{BARTA GYÖRGYI}

\begin{abstract}
BARTA Györgyi: főszerkesztő, kutató professzor emerita; MTA Közgazdaság- és Regionális Tudományi Kutatóközpont, Regionális Kutatások Intézete; 1112 Budapest, Budaörsi út 45.; barta@rkk.hu
\end{abstract}

Györgyi BARTA: editor-in-chief, research professor emerita; Institute of Regional Studies, Centre for Economic and Regional Studies, Hungarian Academy of Sciences; Budaörsi út 45., H-1112 Budapest, Hungary; barta@rkk.hu

1987-ben alapította a MTA Regionális Kutatások Központja (RKK) a folyóiratot, kezdettől fogva nem csak az intézet kutatóinak szánva. Az 1980-as években sokkal szorosabban kapcsolódtunk a területfejlesztő intézményekhez, mint jelenleg, és kutatóink egy része már akkor is tanított különböző egyetemeken. A TéT a „nagy szakma” folyóirata volt és maradt, elsősorban a regionális tudományé, de a társadalomtudomány minden ága, területe számára nyitott.

A három évtized alatt négy főszerkesztő (Tóth József, Beluszky Pál, Rechnitzer János és Barta Györgyi), illetve szerkesztőség váltotta egymást, a 104 lapszámban 1500 írás, köztük 1000 tanulmány, 280 recenzió jelent meg. Egy-egy szám előállításában mintegy 40-50 (szerzők, lektorok, szerkesztők), vagyis egy év során akár 150-200 szakember vesz részt, nem túlzás azt állítani, hogy a Tér és Társadalom „mozgósítja a szakmát”. A tanulmányok válogatásánál a szerkesztőségek és szerkesztőbizottságok, illetve a lektorok tudatosan fordultak a leíró jellegü bemutatástól az elemző, értékelő tanulmányok felé, a magyarországi témáktól a nemzetközi kitekintés irányába, az empirikus vizsgálatokat, területfejlesztési programokat egyre inkább az elméleti kutatások váltották fel.

Vannak problémáink, amelyekkel szinte a kezdetektől fogva küzdünk:

Mivel a regionális tudomány, illetve a Tér és Társadalom interdiszciplináris jellegü, feltételezhető lenne, hogy minket nem sújt a Kornai János (2006) által említett magyar ,átok”, a társadalomtudományok elkülönülése. Valóban, a folyóirat tartalmát tekintve igen sokszínü, viszont a szerzőink munkahelye alapján mégis elég éles intézményi elkülönülés követhető nyomon (50-70\%-uk néhány egyetemről, egyharmaduk saját intézetünkből kerül ki, szerény az érdeklődés más kutatóintézetekből). A nyelvi bezártságunk sem új keletű probléma.

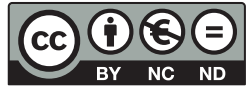


Örök dilemma, hogy mi lenne kedvezőbb tudományunk számára: ha magyarul vagy angolul jelentetjük meg írásainkat? A szerkesztőség hozzáértése, finanszírozási problémák, de az olvasótáborunk igényei és lehetőségei miatt is egyelöre nem válthatunk nyelvet. A tanulmányokhoz füzött részletesebb angol nyelvü absztraktokkal viszont talán sikerül egy-egy téma iránt az érdeklődő, de magyarul nem beszélő olvasó figyelmét is felkelteni.

A szakma korlátozott, sőt az utóbbi időben szükülő mérete (becslésünk szerint 4-500-an rendelkeznek tudományos fokozattal a „szakmánkban”) behatárolja az olvasótáborunkat is. A korábbi 500 példányt 400-ra csökkentettük az elmúlt évben, előfizetőink alig változó számát jelentősen megemeli a Magyar Regionális Tudományi Társaság tagsága, akik illetménylapként kapják a TéT-et. Nem hozott áttörést a digitális megjelenés sem (kedvezményes áron lehet előfizetni online, és háromhavi késleltetéssel ingyen hozzáférhetnek az érdeklődők a TéT-hez). A TéT weblapján jelenleg 900 olvasó regisztrált. Mindezzel együtt ki kell hangsúlyozni, hogy a regionális tudomány müveléséhez, a területi kutatások megjelentetéséhez elemi szükség van a Tér és Társadalomra - más elméleti jellegü folyóirat hiján.

Nem csak a korlátozott példányszám miatt merül fel folyamatosan a finanszírozás problémája. Nincs ma Magyarországon olyan tudományos folyóirat, amely csak az előfizetési díjból tartaná fenn magát. Ez a TéT esetében kezdetektől fogva - 3-5\%-a a kiadás költségének. Eleinte jórészt az RKK finanszírozta a TéT költségeit. Jelenlegi szerkesztőségünk arra törekszik, hogy csökkentse az Regionális Kutatások Intézete terheit. Évek óta sikeresen veszünk részt a MTA, a Nemzeti Kulturális Alap folyóirat-pályázatain, és fontos számunkra a Magyar Regionális Tudományi Társaság rendszeres szponzorálása is. Az évi egy tematikus szám megjelentetésének is az az egyik oka, hogy a vendégszerkesztő intézménye egyben finanszírozza is a számot, vagy jelentösen járul hozzá a szám kiadásának költségéhez. Minden év új kihívás elé állítja az RKI-t (amely felelős a TéT megjelentetéséért) és a szerkesztőket (akik feladatuknak tekintik a források megszerzését is), sikerül-e fedezetet találni a négy számunk költségeire?

Nem kerülhetjük meg a minőség kérdését: vajon a problémáink nem a nem kellően magas színvonal miatt adódnak-e? 2010-ben a MTA IX. osztályának folyóiratai között a Tér és Társadalom az előkelő 3. helyet, a X. osztály folyóiratai között a 8. helyet foglalta el. Jelenleg az MTA Regionális, Demográfiai és Szociológiai Tudományos Bizottságok szerint a Tér és Társadalom „A” kategóriájú, a Gazdaságtudományi Doktori Bizottság szerint „C" kategóriájú. Azt is meg kell említenünk, hogy évek óta küzdünk a Scopus befogadásáért, egyelöre sikertelenül. A szerkesztőségnek az a véleménye, hogy bizonyos kompromisszumokat ugyan meg kell kötnünk annak érdekében, hogy a folyóirat színvonala feleljen meg a „szakmánk” általános tudományos követelményeinek, mindemellett szigorú, anonim, részrehajlás nélküli lektorálással válogatjuk ki a megjelenésre alkalmas tanulmányokat (a beérkezett kéziratok kb. 25-30\%-át utasítjuk el). 
Sikereket is elkönyvelhetünk.

A TéT az utóbbi években - kivétel nélkül - pontosan jelent meg. Nem kellett számokat összevonnunk; hullámzóan ugyan, de mindig volt elég kéziratunk a válogatáshoz, úgy, hogy nem szorultunk másodpublikálásra sem (vagyis másutt már megjelent kéziratokat nem fogadtunk el).

Törekedtünk a folyóirat megújítására is. Új rovatokat vezettünk be: a Vita rovatot a TéT-ben megjelent gondolatok megvitatására; a könyvismertetések helyett kritikus, értékelő írásokat kértünk; a Horizontális Műhely pedig a nagy léptékü, több évre kiterjedő, az RKI vezette, de más tudományos műhelyek részvételével is zajló kutatások tudományos eredményeiről számol be. Nemcsak a TéT küllemének változtatásával (sokra értékeljük a győri Palatia Nyomda pontos és minőségi munkáját), hanem profiljának korábban már említett módosításával is igyekszünk vonzóvá és színvonalasabbá tenni folyóiratunkat.

A legnagyobb sikerünket abban látjuk, hogy a Tér és Társadalom a „nagy szakma” közös teljesítménye, a szerzők, lektorok, szerkesztők együttmüködésének eredménye. Nem mi állítjuk, hanem az írásaikat hozzánk küldők, hogy a TéT-ben publikálni rangot jelent.

\section{Irodalom}

Kornai J. (2006): A társadalomtudományok elkülönüléséről és együttmüködéséről. Közgazdasági Szemle, november, 949-960. 